Portland State University

PDXScholar

\title{
Making Lives, Changing a Landscape: An Environmental History of the Tualatin Valley, Washington County, Oregon
}

Camille A. Cope

Portland State University

Follow this and additional works at: https://pdxscholar.library.pdx.edu/geog_masterpapers

Part of the Human Geography Commons, and the Physical and Environmental Geography Commons Let us know how access to this document benefits you.

\section{Recommended Citation}

Cope, Camille A., "Making Lives, Changing a Landscape: An Environmental History of the Tualatin Valley, Washington County, Oregon" (2012). Geography Masters Research Papers. 4.

https://pdxscholar.library.pdx.edu/geog_masterpapers/4

10.15760/geogmaster.05

This Paper is brought to you for free and open access. It has been accepted for inclusion in Geography Masters Research Papers by an authorized administrator of PDXScholar. Please contact us if we can make this document more accessible: pdxscholar@pdx.edu. 
Making Lives, Changing a Landscape:

An Environmental History of the Tualatin Valley, Washington County, Oregon

by

Camille A. Cope

A research paper submitted in partial fulfillment of the requirements for the degree of

Master of Science

in

Geography

Committee:

Barbara Brower, Chair

David Banis

William Lang

P Portland $\int_{\text {Niversitr }}$

2012 


\begin{abstract}
Sheltered by mountains on all sides, the 724-square mile Tualatin Valley has been home to successive groups of people who have shaped the landscape based on their needs, tools, and ideas about the human relationship to nature. Thousands of years of indigenous burning practices and cultivation of native plants, followed by two centuries of European-American fur trapping, agriculture, logging, and urbanization have created the Tualatin Valley landscape of today. Understanding how a history of changing land use has affected the region is integral to building an environmentally sustainable future.
\end{abstract}




\section{Acknowledgements}

I would like to express my sincere gratitude to all those who helped me throughout the research and writing of this paper. Thank you to Jan Curry at Jackson Bottom Wetlands Preserve for your guidance during the early stages of this project. Dr. Barbara Brower, thank you for encouraging me to pursue a graduate degree and for allowing me the freedom to explore my interests, which were at times wide-ranging. Thank you to my other committee members, David Banis and Dr. William Lang. Your feedback and edits proved invaluable in the completion of this paper. Karin Waller, I couldn't have gotten through the bureaucracy of graduate school without your expertise. Many thanks to you. To my parents, Robert and Linda Duncan, and my parents-in-law, Mark and Rebecca Cope, thank you for your support throughout the process. Thanks to my fellow graduate students, Kate Clark and Stephanie Rohdy, for providing sympathetic ears. Thank you, Corinne Duncan, for your edits and encouragement, and for answering innumerable questions with the knowledge that only an older sister can provide. Amanda McFadden, your friendship and encouragement have been invaluable. And to my loving husband, Mark Cope, thank you for your unfailing belief in my ability to succeed. 


\section{Table of Contents}

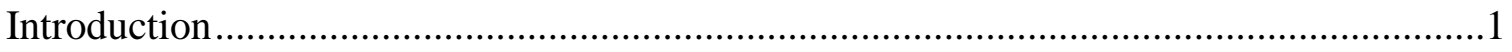

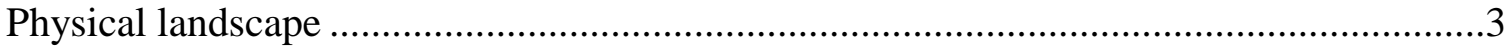

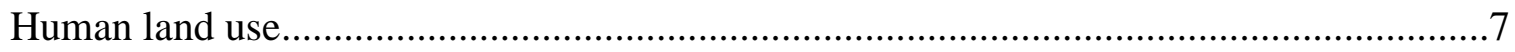

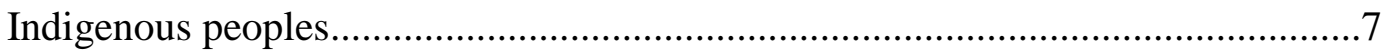

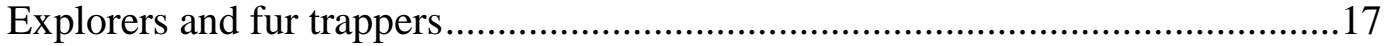

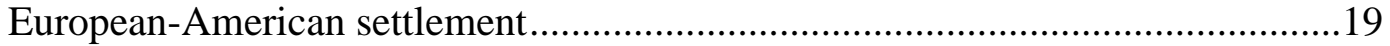

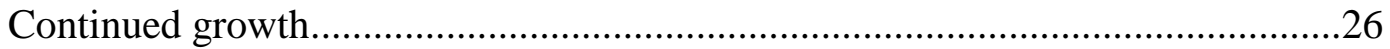

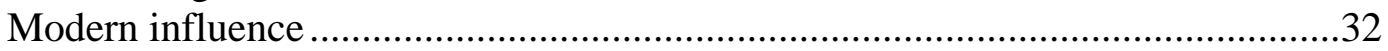

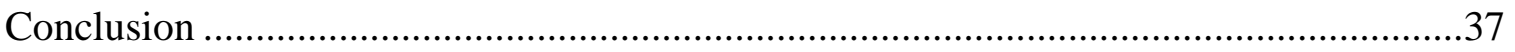

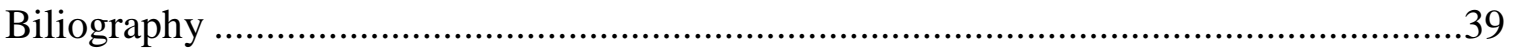




\section{List of Figures}

Figure 1. The Tualatin River Watershed and Washington County.................................4

Figure 2. 1852 Public Land Survey map of northwest Oregon ..................................

Figure 3. Historical Willamette Valley vegetation .................................................9

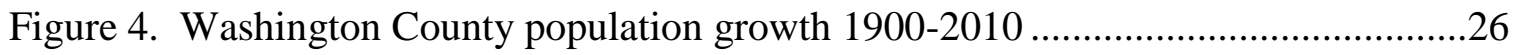

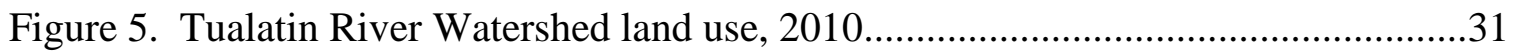

Figure 6. Urban and Rural Reserves in Washington County .......................................33 


\section{Introduction}

Sheltered on all sides by densely forested, low-elevation mountains, the Tualatin Valley's grassy plains, meandering streams, and fertile soils have inspired human settlement for thousands of years. Human groups first made their way into present-day northwest Oregon about 8,000 to 10,000 years ago where they settled along the coastline and in the mountains and valleys to the east. One of the groups of people who moved inland from the coastline were the Atfalati who made their home in the Tualatin Valley. The small valley offered a temperate climate that provided food in its meadows, streams, and wetlands.

Over time, the Atfalati would not be the only people to find refuge in the valley. Thousands of years later, a new group of people, recent immigrants from Europe, would also choose this area to start new lives for many of the same reasons the Atfalati did. Fertile soils and a temperate climate would provide everything they needed to begin a new life in the West. Their effect on the land would be different from their predecessors and continues to impact the landscape today.

The environmental history of this area, human influence on the landscape, is the focus of this paper. Extending beyond the social history of the area (culture and politics) I attempt to describe how human life has affected the natural environment of the valley and the mountains that surround it. Through a series of examples of the different ways that people have lived in the valley I present patterns of life that have shaped the valley's physical and cultural landscapes. Changing land use practices have left their mark on the land and have influenced the way the landscape is both perceived and used today. A 
tradition in academic geography, human-environment interaction studies ask questions about how human perception and subsequent land use affects the natural environment and how the natural environment in turn affects humans, with the goal of better understanding how people relate to the places they live. With an eye towards understanding the influence of human history on the landscape of the Tualatin Valley, this paper seeks to present an environmental history of an area that is both unique in its record as well as generally representative of communities throughout the Pacific Northwest region. 


\section{Physical Landscape}

The Tualatin Valley as we see it today is located within the Willamette Valley of Oregon in the northwest corner of the state (Figure 1). Roughly oval-shaped, the valley is surrounded by low-elevation mountains forested in conifer stands dominated by Douglas-fir (Pseudotsuga menziesii). The Tualatin Mountains (1,000 ft) form the north and east boundaries of the valley, the Chehalem (1,630 ft) and the Parrott Mountains $(1,240 \mathrm{ft})$ mark the boundary to the south, and the Coast Range $(1,500 \mathrm{ft})$ forms the western boundary (Cass and Miner 1993, 3). The forests cloaking these mountains include a high diversity of plant and animal species. Sitka spruce (Picea sitchensis), Douglas-fir (Pseudotsuga menziesii), western red cedar (Thuja plicata), western hemlock (Tsuga heterophylla), huckleberry (Vaccinium spp.), oceanspray (Holodiscus discolor), and a variety of ferns thrive in the mountains' temperate rain forests. Black-tailed deer (Odocoileus hemionus columbianus), elk (Cervus elaphus), black bear (Ursus americanus), western gray squirrels (Sciurus griseus), birds, amphibians, and copious insects take residence among the mountain vegetation.

Historically, the valley floor provided habitat for oak trees (Quercus garryana) and perennial grass species; Festuca rubra and Deschampsia cespitosa dominated the grasslands. Camas (Camassia quamash), wild onion (Allium spp.), and wapato (Sagittaria latifolia) thrived in the low-elevation marshy areas surrounding lakes, such as the now-drained Wapato Lake located just outside the current city of Gaston at the base of the Chehalem Mountains (Boyd 1999). Moving from the dense vegetation cover of the forested areas, deer and elk herds grazed on the valley floor, while great blue herons 


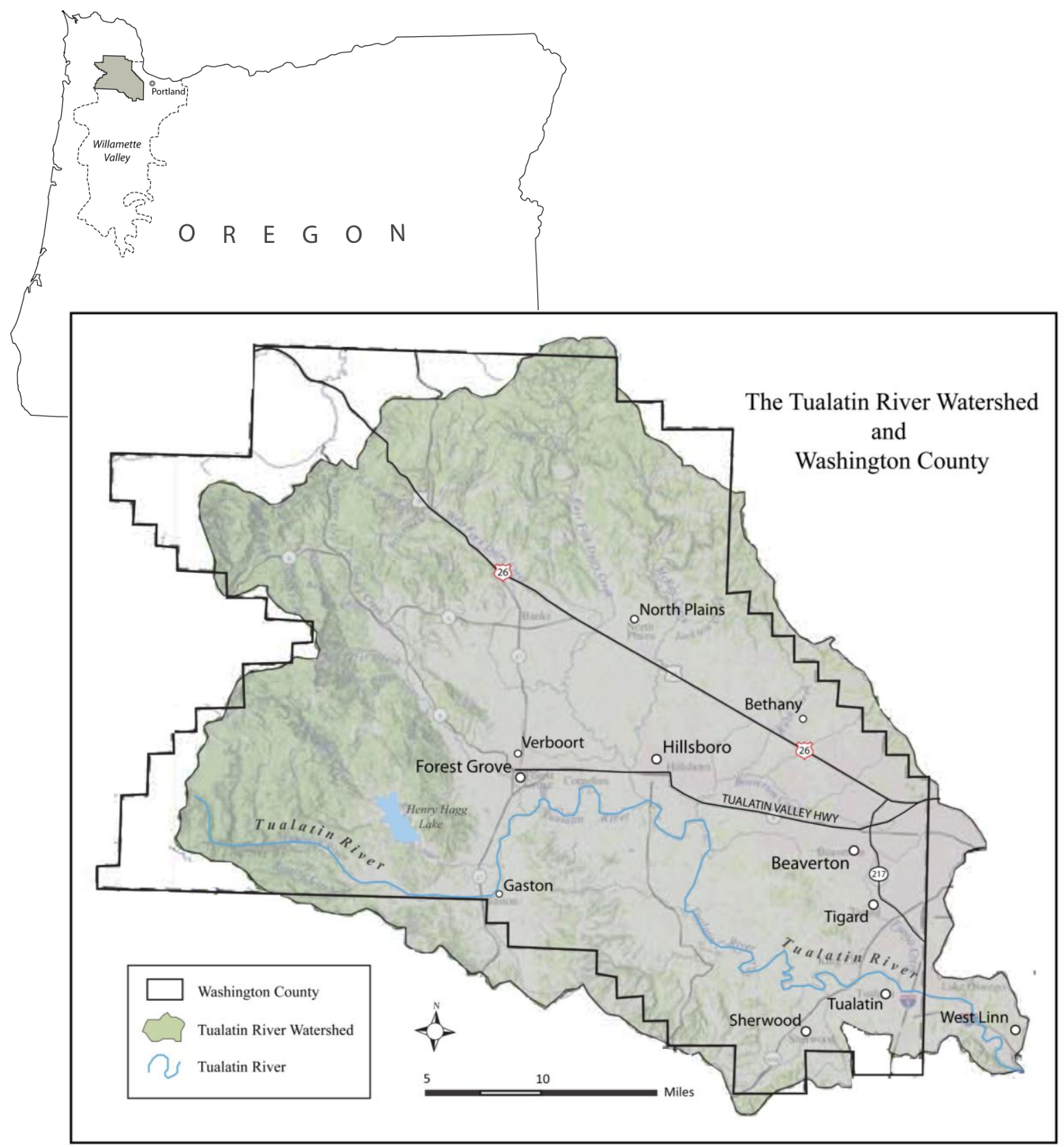

Figure 1. The Tualatin River Watershed and Washington County.

(Adapted from a Tualatin River Watershed Council map: http://www.trwc.org/tualatin-info/atlas-maps.html) 
(Ardea herodias), ducks (Anatidae spp.), geese (Branta canadensis), beaver (Castor Canadensis), and river otter (Lontra canadensis) lived in the streams and wetlands that constituted a major portion of the valley.

The contemporary climate in the valley is temperate, with wet winters and dry summers. Moderated by its proximity to the Pacific Ocean, summer and winter average high temperatures differ by only about 28 degrees Fahrenheit; the summer average high temperature from 1948 to 2003 was 77 degrees while the winter average high temperature during the same time period was 49 degrees. Rainfall averages around 40 inches, most of which falls during the winter months. Streams in the watershed rely on this rainfall, as do Tualatin Valley residents who use the water for household, agricultural, and industrial purposes (WRCC 2003, TRWC 2012).

About 83 miles long, the Tualatin River is the largest tributary of the Willamette River. It flows out of the Coast Range, snakes eastward through the valley, and finally exits into the Willamette River through a depression at about 100 feet above sea level near the present-day city of West Linn (Figure 1). The river has eight main tributaries: the Wapato, Scoggins, and Gales Creeks that drain parts of the Coast Range to the west of the valley; the Dairy and Rock Creeks that drain the Tualatin Mountains to the north and east; the McFee and Chicken Creeks that drain a portion of the Chehalem Mountains along the valley's southern border; and Fanno Creek which drains the Portland Hills in the east end of the valley (Cass and Miner 1993).

During the Missoula Flood period 15,000 to13,000 years ago, the Tualatin Valley was inundated, creating a landscape dominated by wetlands (Benson 1975; 1978; Beckham et al. 1981; Zyback 1990; Cass and Miner 1993, 3). On a more recent time 
scale, the Tualatin River once flooded the valley routinely. Described as "mostly water connected by swamps" by a fur trapper in 1825 (Sedell and Luchesa 1982; Shively 1999), rainfall, high water tables, and flat topography combined to create a flood-prone landscape with marshy prairies and wetlands. High flood frequency was also attributed to beaver damming and the associated high accumulation of organic materials and sediment within stream channels (Sedell and Luchesa 1982; Sedell and Froggatt 1984; Mitsch and Gosselink 1986; Shively 1999).

The slow-flowing, flood-prone nature of the Tualatin River helped to create much of the character of valley by influencing the location of settlements as well as how residents would use, and subsequently alter, the land. 


\section{Human Land Use}

\section{Indigenous peoples}

The most effective attempts at mapping the vegetative environment pre-European contact have used early 1850s Public Land Survey records (Figure 2). These reconstructions indicate that, during this time in history, most of the Willamette Valley was open grassland habitat with scattered oaks. In the northern portion of the Willamette Valley, especially the Tualatin Valley, wetlands and lakes also constituted a major portion of the landscape (Figure 3) (Johannessen et al. 1971; Habeck 1961; Towle 1982; Boyd 1999; Christy and Alverson 2011). Dense, timber-lined waterways and surrounding areas were prone to dramatic seasonal flooding, creating marshes and wetlands that persisted through all or most of the year (Matthews 1988).

More recently, palynological studies indicate that the Willamette Valley was dominated by oak savannah habitat for more than 6,000 years. This habitat type appears to have originated during the Hypsithermal period $(8,000-4,000 \mathrm{BP})$ when the climate was warmer and drier, preventing a closed-canopy forest from developing. However, since this period of warm, dry climate ended, the oak savannah habitat persisted even though the new (cooler and wetter) climate would have allowed for widespread forest invasion throughout the valley. This persistence has been attributed to the annual burning practices of the indigenous people who lived in the valley (Habeck 1961; Johannessen et al. 1971; Towle 1982; Boyd 1999). 


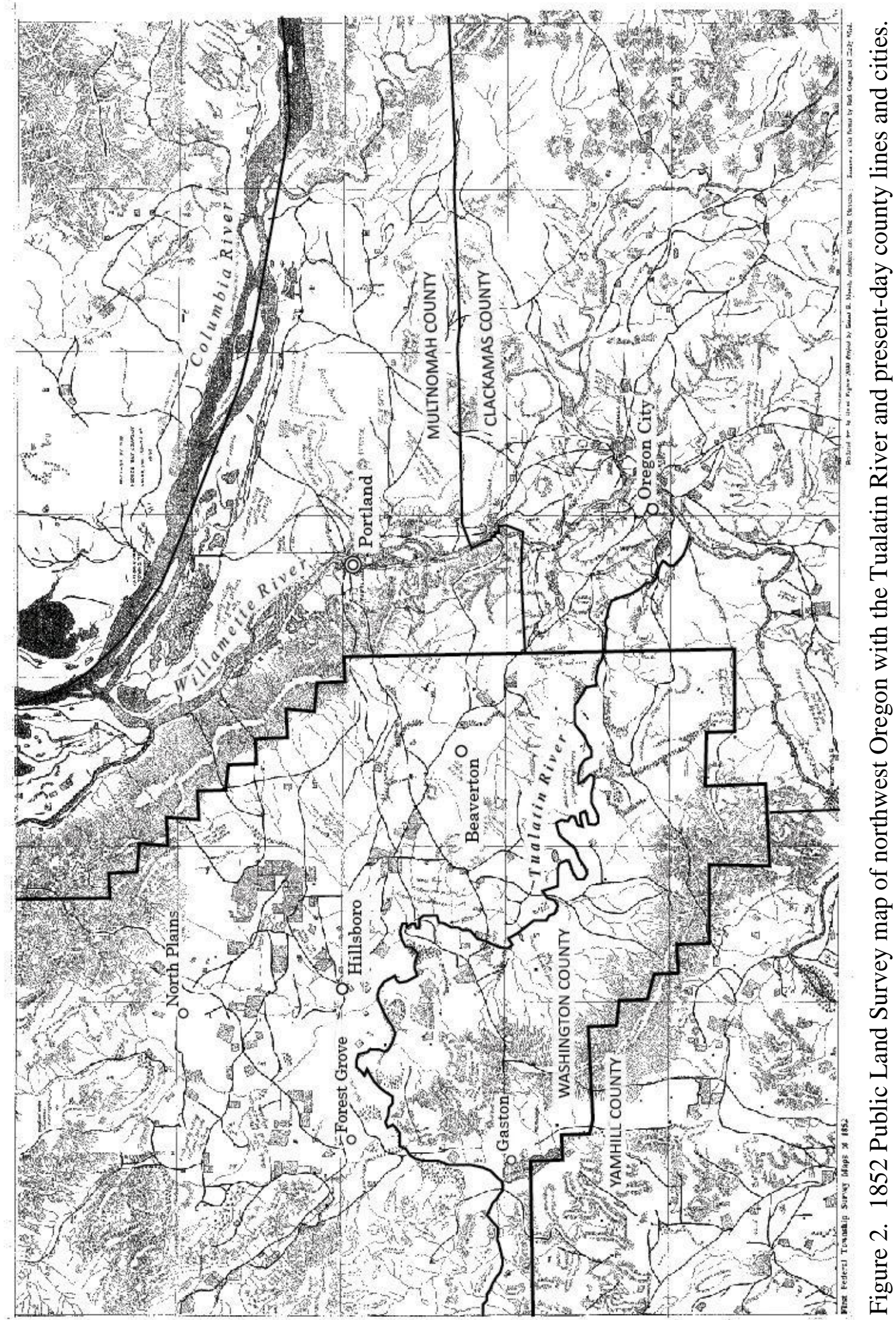




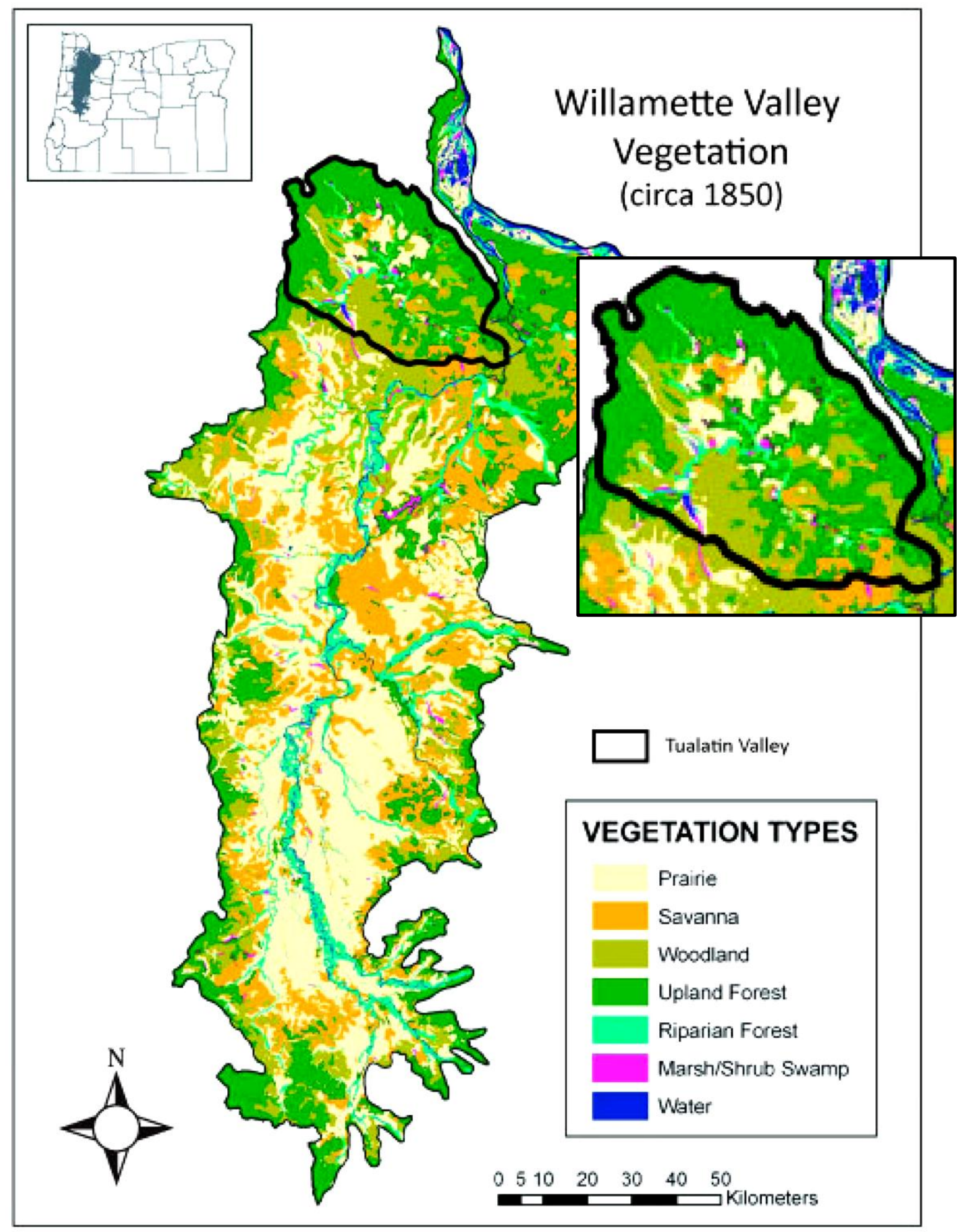

Figure 3. Historical Willamette Valley vegetation (Adapted from Christy and Alverson 2011). 
The first people to inhabit the Willamette Valley were the Kalapuyans, who arrived 8,000 to 10,000 years ago. The tribe was divided into at least twelve different bands; each occupied its own territory and had individualized ways of living, but all are generally reported to have participated in hunting, fishing, gathering, and cultivating (Beckham 1977). The Atfalati band who lived in the Tualatin Valley moved between winter homes and summer villages located throughout the valley. From their permanent winter homes around Wapato Lake in the southern edge of the valley, the Atfalati traveled to Willamette Falls just outside the eastern end of the valley to fish or trade for salmon in the spring. Then, in the early summer months, women and children gathered berries throughout the interior of the valley and, as the summer months progressed, they gathered both hazelnuts as well as insects such as caterpillars and grasshoppers. In the fall, elk and deer hunting began in the surrounding mountains, while gathering of tubers such as wapato, camas, and wild onion commenced in the wetland areas. As the fall turned into winter and food stores emptied, fishermen went to rivers within the valley, especially the Tualatin, to catch steelhead (Oncorhynchus mykiss) and other fish.

Fire was an important tool for many Kalapuyan tribes. Usually ignited in late summer or early fall, it was used to create open valleys suited for hunting deer and elk and for maintaining growth of plants for food, fuel, building materials, clothes, medicine, and tools (Beckham et al. 1982; Boyd 1999; Lepofsky and Lertzman 2008; Christy and Alverson 2011). This use of fire maintained the oak savannah habitat and allowed for traditional subsistence in an area that would have naturally reverted to a Douglas-fir forest (Habeck 1961; Johannessen 1971; Towle 1982; Boyd 1999). By discouraging less economically important plants from encroaching on desired plants' habitat (Lepofsky and 
Lertzman 2008), the Atfalati were able to manage vegetation in a way that enhanced the growth of plants that were economically important to them. For example, without regular use of fire, Douglas-fir trees would have invaded prairies and shaded out huckleberry bushes and tarweed (Madia elegans), both of which provided important food sources in the forms of berries and seeds. Evidence of this encroachment is seen today all around the valley where fire suppression has taken precedence.

Like other indigenous groups that lived across North America, reasons for using fire among the Kalapuya were varied. Anthropologist Omer Stewart was one of the first people to record in detail the practices of aboriginal burning. Although never published, he gave detailed accounts of the reasons that Native American groups used fire for food production:

Although fire is reported most frequently used to aid hunting- to encircle, to rouse, to stampede- fifteen other reasons for setting fires are given. These were as follows; to improve pasture, improve visibility, collect insects, increase yield of seeds, increase yield of berries, increase other wild vegetable foods, make vegetable food available, remove or thin trees to allow other growth, clear land for planting, stimulate growth of wild tobacco, aid in warfare, produce a spectacle, and reduce danger from snakes, insects, etc." (Stewart in Boyd 1999).

In most cases, the location and timing of burns was carefully planned and managed by people knowledgeable in fire ecology (Lepofsky and Lertzman 2008). Forest edges maintained through annual burning of the valley floor provided a variety of 
fruit and vegetable foods such as salal (Gaultheria shallon), Oregon grape (Berberis spp.), blackberries (Rubus spp.), raspberries (Rubus spp.), and huckleberries (Vaccinium spp.) (Boyd 1999; Robbins 1999). The prairies maintained through frequent firing provided habitat for tarweed, the seeds of which were collected to make flour, and grasshoppers, also collected as food after a fire (Minor et al. 1980). While most evidence of this type of fire use by indigenous people in the Willamette Valley comes from postEuropean settlement records, continuing changes in local vegetation structures suggest widespread changes in ancient fire regimes. Hadley's (1999) analysis of fire scars demonstrates that fires were more frequent in the Willamette Valley before EuropeanAmerican settlement and were also more frequent in the valley than in the surrounding forest. This evidence of higher-frequency fires in the valley indicates an anthropogenic source rather than a natural, lightning-ignited one. The decline in fire frequency after European-American settlement in the area is consistent with European-style fire suppression (Lepofsky and Lertzman 2008).

Historical evidence of the effect that indigenous burning practices had on landscapes comes from several sources. Explorers on George Vancouver's expedition in the early summer of 1792 reported a park-like atmosphere in the Puget Sound area that likely extended further south into the Willamette Valley:

The surrounding country, for several miles in most points of view, presented a delightful prospect consisting chiefly of spacious meadows elegantly adorned with clumps of trees; among which the oak bore a very considerable proportion, in size from four to six feet in circumference. In these beautiful pastures... the deer were seen playing about in great 
numbers. Nature had here provided the well-stocked park, and wanted only the assistance of art to constitute that desirable assemblage of surface, which is so much sought in other countries, and only to be acquired by an immoderate experience in manual labour (Vancouver 1791-1795, vol. II in Boyd 1999).

While Vancouver believed that natural processes were to be credited for the romantic, park-like view he enjoyed, it was most likely Native American manipulation of the land through targeted fire use that created the scenery so appealing to EuropeanAmerican explorers. Extrapolating this description of the Puget Sound region to the Willamette Valley, the most intensively fire-managed region in the Pacific Northwest (Boyd 1999), one can imagine the extent of the Kalapuyan's manipulation of the landscape.

A more recent account of the effects of indigenous burning practices in the Pacific Northwest comes from anthropologist Jay Miller in 1979:

[I] went into the Methow Valley [north-central Washington] with a van load of [Methow Indian] elders, some of whom had not been there for fifty years. When we had gone through about half the valley, a woman started to cry. I thought it was because she was homesick, but, after a time, she sobbed, 'When my people lived here, we took good care of this land. We burned it over every fall to make it like a park. Now it is a jungle.' Every Methow I talked to after that confirmed the regular program of burning (Letter to Robert Boyd from Jay Miller, May 28, 1996 in Boyd 1999). 
Descriptions like these confirm research that suggests that indigenous burning practices, along with occasional lightning-ignited fires, were widely responsible for creating the now almost-extinct landscape that sustained indigenous populations and greeted early European-American explorers (Robbins 1999).

While fire created large-scale changes across the landscape, cultivation of native plants also resulted in changes in vegetation structure (Saikku 2005). While little research has been conducted in the Tualatin Valley on the topic, it is known that cultivation to enhance desired plants' productivity was widely practiced among indigenous people in the Pacific Northwest (Lepofsky and Lertzman 2008). The intensity of cultivation varied from casual manipulation to regular management of plants. Plants could be either directly selected for positive traits in order to enhance productivity in subsequent generations or whole ecosystems could be manipulated through the use of fire and soil modification such as tilling. Indigenous cultivation practices included activities commonly associated with gardening; preferred areas for collecting were known, areas were sometimes delineated with markers, plants could be transplanted, and growing areas could be enhanced by weeding, burning, tilling, removing rocks, and using mulch (Saikku 2005, Lepofsky and Lertzman 2008). Over years of selective cultivation and burning, the Atafalti likely enhanced growing conditions for huckleberry, camas, wapato, and other important food sources.

For the Atfalati, wetlands were another important source of food and materials. Grasses, sedges, and rushes were used for basket-making, roof construction, and seed for food. Birds, fish, beaver, and otter could be hunted in the wetland while elk and other large game could often be hunted nearby (Vileisis 1999). Seasonal flooding created 
marshy areas around lakes, including Wapato Lake, named for the extensive amount of wapato that grew there. The lake was important to the tribe; during the winter, they lived in twenty-three permanent villages located around the shallow 1,500-acre lake (Buan 1999; USFWS 2007). Several other tubers also favored the marshy growing environment including camas and wild onion (Boyd 1999). The Atfalati preferred these foods and likely enhanced their productivity by actively selecting plants that produced large tubers, transplanting highly productive individuals, as well as possibly modifying the plant's local environment by intentionally flooding areas or applying fertilizer (Saikku 2005, Lepofsky and Lertzman 2008).

Over the course of several thousand years, the Atfalati's land use patterns left an impression on the landscape. Their annual burning practices ensured the continuation of savannah and prairie ecosystems and enhanced the growth of camas and other plants, creating a landscape later described poetically as, "grassy stretches... glisten[ing] with the sky blue flower of the wild hyacinth, the camas plant" (Benson 1976; Matthews 1988). The promotion of the growth of desirable plants in prairies, wetlands, and along forest edges through the use of fire and cultivation indicates that, in tandem with the discouragement of forest encroachment, the Atfalati created a landscape suited to their particular way of living.

While the Atfalati had established a successful mode of life, foreign diseases would ultimately decimate their population. As explorers and fur trappers passed through the area, diseases that the Atfalati were not immune to spread through their population. Smallpox reduced many Native American populations throughout Oregon as well as the Tualatin Valley during an epidemic from 1782-83, venereal diseases were introduced in 
the 1790 s, and a malaria epidemic that lasted from 1830 to 1833 further devastated the Atfalati and other indigenous populations in the Pacific Northwest (Minor et al. 1980; Robbins 1999; Boyd 1999; Buan 1999; Walsh et al. 2010; Christy and Alverson 2011). By the time European-American settlers began moving into the Tualatin Valley in the 1830s, the Atfalati population had been reduced to a fraction of its former size and the few survivors were so weakened from hunger and disease that they could no longer produce enough food to feed their remaining population.

Despite their weakened state, the Atfalati resisted relocation for many years and negotiated for a reservation at Wapato Lake. In 1855 the request was denied, however, and the small remaining group of Atfalati were relocated to the Grand Ronde reservation in northwest Oregon just west of the Willamette Valley (Zenk 1976; Buan 1999). As they moved from their homeland, they left a landscape influenced by fire and the cultivation of native plants; a landscape that would soon be transformed by new forces. 


\section{Explorers and fur trappers}

The fire-treated, park-like landscape managed by the Atfalati in the Tualatin Valley greeted early European explorers and suggested an inviting site for settlement. At the same time that Spanish, French, and British explorers were surveying the west coast for potential resources, the United States' government was also becoming interested in learning how the continent's western lands could be exploited economically. President Thomas Jefferson, especially interested in water commerce opportunities, contracted with Meriwether Lewis and William Clark to complete an expedition across the North American continent from 1804 to 1806 (Lang et al. 2004; Woodger and Toropov 2004). While the gathering of scientific and geographic information was an important element of the expedition, President Jefferson made their primary objective clear: "The object of your mission is to explore the Missouri River, \& such principle streams of it, as by its course...may offer the most practicable water communication across the continent for the purposes of commerce" (Woodger and Toropov 2004).

While the expedition ultimately resulted in the knowledge that there was no direct water route across the continent (the fabled Northwest Passage) (Lang et al. 2004) it contributed to the knowledge that lands in the Pacific Northwest, including the Tualatin Valley, were fertile and suitable for agriculture.

Beginning around the same time that Lewis and Clark made their observations about the agricultural value of land in the valley, fur trappers, mainly from French Canada, came to the West in search of beaver and other fur-bearing animals. The trappers originally ventured into the West only temporarily in search of adventure and money rather than settlement. But, as fur-bearing animal populations dwindled from 
over-hunting, and the market for beaver evaporated, the fur trade slowed and mountain men began to settle throughout the West. In the Tualatin Valley, Joseph Meek, a famous fur trapper and mountain man, was one of the first European-American people to settle. He, along with a few other trappers from the Rocky Mountains, arrived in the valley in December 1840 and made their camp at the foot of the Chehalem Mountains near Wapato Lake in the southeast section of the valley. After a rough winter, the group began farming because they felt it was their only option after the fur trade died out (Tobie 1949; Moore 1975; Victor 1985; Buan 1999).

Even before the farms they established could create widespread changes in the valley, their fur trapping activities had resulted in substantial changes in wetland ecology. As beaver populations were depleted, stream and wetland hydrologic systems lost an integral component. By building dams, beavers altered local hydrology, channel geomorphology, and nutrient composition in streams throughout the valley. The dams increased flooding as well as established and maintained marshes and wetlands which in turn captured stream sediments and processed and stored stream nutrients. Loss of beaver and the ponds and dams they created also resulted in fewer streamside marshes as well as fewer meanders off main stream channels. Important habitat for birds, salmonids, and many invertebrates, the loss of beaver-created wetlands resulted in substantial ecological changes for the region (Vileisis 1999). 


\section{European-American settlement}

Over time and with use by mountain men and fur trappers, the Oregon Trail eventually became passable by wagon and became a conduit for an increasing stream of settlers. In 1841 some of the earliest pioneers, David Hill, Isaiah Kelsey, and Richard Williams, settled in the area that would later become the county's seat, Hillsboro. A few years later, the passability of the trail by wagon greatly increased European-American population in the area and a large number of settlers arrived in the valley in 1843 (Bowen 1978; Christy and Alverson 2011). Many of these new settlers made their homes in the west plains in the area that would later become the City of Forest Grove. In 1850, the census counted over 11,000 settlers in the Willamette Valley, the Tualatin Valley being the most populated area (Bowen 1978). For these early settlers, as for many other pioneer groups across the West, survival was the main goal. Building cabins using logs harvested from the surrounding mountain forests required intense labor. Without sawmills, creating boards was difficult, so early structures were often primitive. Seeing a need, several different families opened sawmills in the valley (Buan 1999; Bilderback 2011), providing a foundation for the timber industry that would arrive early in the next century.

As these new settlers established their homes, widespread changes in the landscape began to take form. The continuing influx of immigrants that flowed into the valley would change both the cultural and the physical landscapes almost beyond recognition. A major portion of this change lay in the implementation of agriculture. Like the fur trappers who began European-American settlement in the Tualatin Valley, other new settlers used intensive agricultural practices that required converting river 
valleys, along with the wetlands and marshes they encompassed, into agricultural fields. Flat, wet prairies and wide floodplains like those found in the Tualatin Valley were especially vulnerable to agricultural conversion. Their fertile soils and lack of trees and brush made them appealing to pioneer farmers (Dahl 1990; Vileisis 1999; Mitsch and Gosselink 2000; Taft and Haig 2003). After centuries of annual burning by indigenous people, the prairie landscape appeared ready-made for agriculture and the mechanical plowing that it required.

Unlike the indigenous Atfalati who used wetlands for food, building materials, and medicine, European-American settlers treated wetlands as an impediment to both their health and the expansion of their communities. Prior to the westward pioneer movement, wetlands in the East had become infested with malaria imported from Europe. Because of this, dry land crops had become more appealing to cultivate than wetland ones and, as cities needed more room to grow, wetlands began to look increasingly more like an obstacle than a resource (Vileisis 1999). Bringing this Eastern mindset with them to their new homes in the West, settlers set about draining and filling wetlands in the Tualatin Valley. Relief from somewhat unpredictable flooding made the development of agriculture and infrastructure possible (Saikku 2005) in the Tualatin Valley. By the year $2007,127,984$ acres (28 percent) of the valley's land would be devoted to agriculture (ODA 2012).

As the federal government began to recognize the significance of settlement in the Oregon territory, the Oregon Donation Land Act of 1850 was created. The Act granted up to 320 acres to European-American settlers, men and women alike, who had settled in Oregon prior to 1853; married couples could hold up to 640 acres (CCRH 2012). Feeling 
secure in their claims, the new settlers continued building houses and plowing new fields (Buan 1999). These large tracts of land defined the landscape as agricultural and continue to define many areas of it in the same way today.

In 1862, the United States government again promised land to EuropeanAmerican settlers willing to improve it; this time 160 acres for individuals and 320 for married couples (CCRH 2012). Improvement most commonly meant putting land under cultivation, draining wetlands, or building. With the Homestead Act, the EuropeanAmerican population grew more quickly than ever before. Throughout the rest of the nineteenth century as well as into the early twentieth century, European-American immigration continued. As railroads reached the Pacific Northwest in 1882, the area became an even more popular destination for European immigrants who viewed the area as a chance to begin new lives, a mindset that was encouraged by targeted railroad advertising. As more farms became established and more profit was made from the sales of fruits and vegetables, the local economy boomed (Bowen 1978; OHS 2011).

As more immigrants moved into the valley, ethnic enclaves sprouted up around the developing county. Swiss and German immigrants from the Midwest settled together and built churches that offered German language services to the surrounding community of Bethany. A group of Dutch immigrants, bringing tulip bulbs with them, settled to the west in an area they named Verboort. A crop specially bred for the region's damp climate was onions; Italian families specialized in growing them and developed a large area known as the "onion flats" between the present-day cities of Tualatin and Sherwood. Each of these ethnic groups left their mark on the landscape. Street names, churches, and tulip festivals are modern evidence of these early settler's lives in the valley (Buan 1999). 
The structures these immigrants constructed contributed to the ongoing expansion of the built environment, an environment that was becoming increasingly unrecognizable from the valley that had glittered with camas just fifty years earlier.

In 1906, the Oregon Nursery Company, looking to expand their business, moved from Salem into the area just northeast of Hillsboro. Using an acronym of the company's name, Orenco became a successful company town; two years after its establishment the area had five-hundred residents as well as a fire station, post office, school, newspaper, and church. The nursery itself covered twelve-hundred acres (previously a Donation Land Claim) and supplied trees to orchardists across the county; apples, pears, and peaches were sold for substantial profit to individuals as well as canning companies (Buan 1999; Slater 1965). Tilling land previously untouched by mechanical plowing, the nursery replaced native vegetation with thousands of non-native trees. Remnants of this orchard can still be seen today.

Himalayan blackberry (Rubus armeniacus), the most widespread noxious weed in western Oregon and the Tualatin Valley was first noted in Oregon in 1922 (ODA 2012). The weed establishes most effectively in disturbed soils; large-scale plowing operations like those used in nurseries and other agricultural endeavors likely allowed it to gain a strong presence in the Tualatin Valley. Along with the introduction of foreign, sometimes invasive, species, the agricultural industry reshaped the landscape and further defined the locations of settlement. The first few decades of the twentieth century emphasized the importance that agriculture had, and would continue to have, in the Tualatin Valley. Like businesses across the country, the Great Depression that began in 
1929 brought the Oregon Nursery Comapny, and the surrounding town, to its demise (Buan 1999).

In Gaston, fifteen miles southwest of Orenco, landowners prepared to reclaim farmland lost to the reemergence of the former Wapato Lake. Land was especially needed to grow food during the Great Depression and, after a failed attempt nearly fifty years earlier, Gaston landowners in the mid-1930s formed the Wapato Improvement District (WID) as an organized effort to better prepare the area for agriculture. After the lake had been wrested from the Atfalati's ownership through a series of bad deals in the mid to late 1800s, Congress offered the land free of charge to anyone willing to drain it for use as farmland (Bilderback 2011). From this offer, an attempt in the late 1800s resulted in a drained and filled lake that was still oftentimes reclaimed by nature during the winter rains. The second attempt in the mid-1930s aimed to be more effective. The WID's attempt was mostly successful and the area was mainly used for large-scale onion production. In spite of the two drainage projects however, remnant communities of riparian habitat and small wetland habitats persisted. Today, in response to public demand and the need for wildlife habitat, the U.S. Fish and Wildlife Service are putting together plans to reverse much of the agricultural conversion described above (USFWS 2007).

While agriculture played an important role in the changing landscape of the Tualatin Valley, so too did other industries. Creating landscape changes throughout the watershed, timber production in the mountains surrounding the Tualatin Valley was successful from the early 1900s until the 1930s when the Great Depression halted demand and the Tillamook Burn (described later) halted supply (Buan 1999). Railroad 
lines were installed throughout the surrounding mountains, logging towns sprouted up along the tracks, large areas of forest were cleared, and log drives and splash dams caused major changes in channel geomorphology and stream composition throughout the watershed (Sedell and Luchesa 1982; Sedell and Froggatt 1984; Shively 1993; Buan 1999). As larger trees were extracted from the forest and ox-driven power was no longer enough, log drives became the most popular means of getting timber to the mills. In order for this technique to work, stream flow had to be constant with no obstructions; boulders, leaning trees, and large woody debris were subsequently removed from much of the Tualatin River and its tributaries. To ensure that logs stayed in the main stream channel, outlets to swamps, marshes, and wetlands were blocked off (Shively 1993) resulting in further loss of many marsh and wetland areas throughout the valley. In addition to log-driving, splash dams were another popular method used to transport logs downstream to mills in the valley (Beckham 1990; Miller 2011). By constructing a dam across a section of the river, storing water and logs behind it, and then opening the spillway, large quantities of water were released downstream in a torrent that carried the timber along with it (Beckham 1990; Shively 1993; Miller 2011). Especially damaging to rivers, splash-damming operations sometimes used dynamite to destroy the dam and create enough power to push large quantities of logs downstream (Beckham 1990). Over time, this method scoured the stream beds down to bedrock (Miller 2011), thus destroying stream habitat and channel complexity. Splash damming has been identified as a significant historical cause of stream simplification, and the corresponding decline of salmonid species, throughout the Pacific Northwest (Lichatowich 1999; Taylor 1999; Miller 2011). 
During this time, habitat simplification also occurred throughout the rest of the valley because of lack of human-ignited fire as well as the suppression of naturallyignited ones. Researchers agree that the oak-savannah habitat of the Willamette Valley was an early seral community moving towards a Douglas-fir dominated climax community (Habeck 1961; Johannessen 1971; Towle 1982; Boyd 1999; Christy and Alverson 2011). As described earlier, this progression toward a climax community was intentionally halted by indigenous burning practices. However, as European-American settlers built homes and put more land under cultivation, fire suppression became a priority. Since European-American settlement began in the Tualatin Valley, forest cover has increased dramatically and now covers most rural areas that are not being used for agriculture. In most areas, Garry oak (Quercus garryana) has been replaced by Douglasfir and big-leafed maple (Acer macrophyllum) because of its inability to reproduce in shade (Boyd 1999).

European-American settlement in the valley left its mark in a relatively short amount of time. Beginning as small land-holdings, family farms quickly grew into large agriculture businesses, setting the stage for continued population growth. Native plants were plowed under, non-native and invasive ones introduced, wetlands drained, and wildlife habitat pushed aside in favor of new towns. The timber industry took hold in the mountains sheltering the valley, providing jobs to hundreds of men, but coming with consequences as well. Giant, old-growth trees were felled, streambeds were scoured, and habitat lost. Human habitation took a dominant stance over all other types, foreshadowing a trend sustained far into the future. 


\section{Continued growth}

Technological advances that began in the mid to late 1800 s and continued on into the next century allowed towns all across the country to grow more rapidly. Trains and automobiles made getting in and out of the Tualatin Valley more efficient, while electricity, the telephone, central water supplies, and sewage systems made living there easier. The population of Washington County grew from less than 15,000 people in 1900 (US Census Bureau 2012a) to nearly 530,000 people in 2010 (US Census Bureau 2012b) (Figure 4). World War II and the subsequent baby boom from 1945 to 1960 and the high-tech industry that began moving into the valley during the end of the baby boom have especially contributed to population growth. Rapid urban growth and its corresponding strain on natural resources and the local environment have created much of the physical and cultural elements we see on the landscape today.

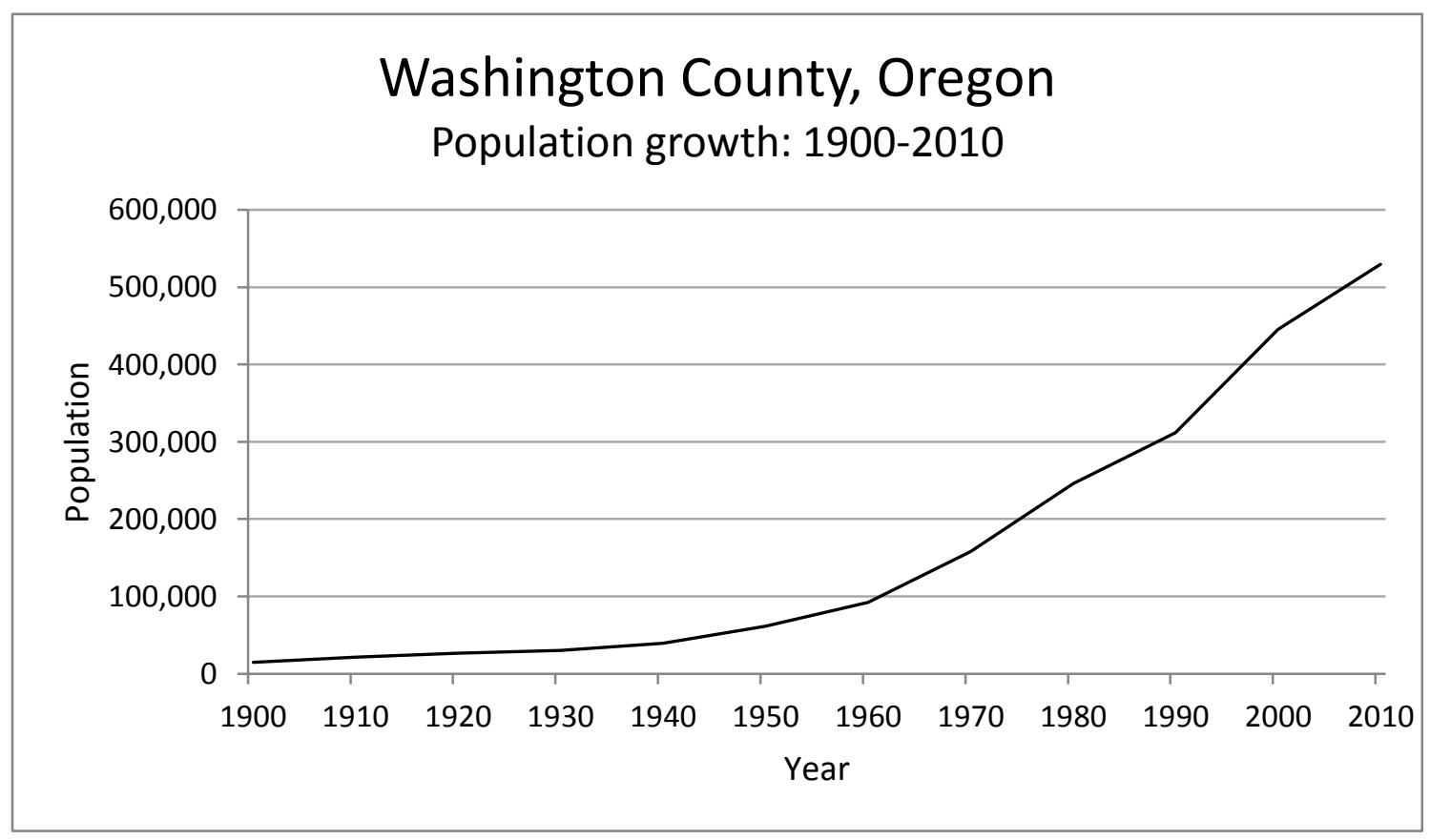

Figure 4. Washington County population growth 1900-2010 (US Census Bureau 2012a, 2012b). 
In 1908, electric-powered commuter trains provided frequent service in an out of the valley, beginning a tradition of train commuting that would last well into the twentyfirst century; the Metropolitan Area Express (MAX) electric light rail train opened in 1998 follows the same route as these early passenger trains (Robbins 1976; Buan 1999). No longer isolated from the outside world, railroads were a key factor in creating the metropolitan region we know today.

Like trains, automobiles had substantial impacts on population, often influencing both the rate of growth as well as the location of it. As automobiles became popular in Washington County, highways not only connected towns and cities to areas outside of the county, but also guided the growth of urban areas. With the construction of the Tualatin Valley highway in the 1920s, many businesses were forced to abandon their main street locations and move to places along the new highway (Buan 1999). This pattern of growth created the strip development that is apparent in many parts of Washington County today.

As the Great Depression hit the region in the 1930s, development and population growth slowed. Due to the economic downturn, the railroads that had been popular in previous decades quit offering passenger service, resulting in loss of revenue for businesses that depended on the railway. As the Depression took its toll on Washington County, projects of the Civilian Conservation Corps (CCC) and Works Progress Administration (WPA), established in 1933 and 1935, provided temporary employment for some Washington County residents. In 1933, the WPA and CCC began construction on the Wolf Creek Highway, later re-named U.S. Route 26 (Barker 2000; Tucker 2002). 
The work would not be completed until after the end of World War II in 1949 in response to demand for living space outside the City of Portland (Robbins 2002). In Hillsboro, Shute Park received improvements through the labor of CCC and WPA workers and a sewage treatment plant was built as well (Buan 1999). Ironically, effluent from the sewage plant was discharged into the wetland that, later in the century, would be restored and turned into the Jackson Bottom Wetland Preserve.

Also during this time, a series of large fires swept through the forest in the western end of Washington County as well as portions of Yamhill and Tillamook Counties in an area later named the Tillamook Burn. In 1933, the first and largest of the series was started in the forest west of the City of Forest Grove during a logging operation when a large Douglas-fir log was dragged across a downed tree. The friction created between the two trees, along with record high temperatures and dry forest conditions, was enough to start a fire that would burn 240,000 acres. Over the next eighteen years three more fires, all attributed to logging operations, ignited the forest (Wells 1999; Decker 2012). Salvage operations kept some mills open, but the fires, in conjunction with the Great Depression, ultimately put an end to the timber industry in the area (Meyer 1978; Buan 1999).

From 1940 to 1944 , World War II created more change throughout the Tualatin Valley. Young men were drafted into service, war-time tasks took precedence, JapaneseAmericans were forced from their homes, and migrant workers from Mexico immigrated to the county as agricultural workers (Buan 1999). Specializing in berries, particularly strawberries, Japanese-American families produced large-scale crops that were commercially successful. With the bombing of Pearl Harbor by the Japanese in 1941 and 
the United States' subsequent entry into World War II, Japanese-Americans in the Tualatin Valley, like areas across the Pacific West, were sent to internment camps. While they were imprisoned, many of these families lost both their lands and their belongings. During this time, the United States' government implemented the Bracero Program, which aimed to replace the loss of both Japanese-American workers (who were either in internment camps or fighting against the Axis powers in the war overseas), as well as European-American workers (who were also busy with wartime tasks), with migrant workers from Mexico. After the war ended, many Mexican families permanently settled in the valley (Buan 1999). Strawberry farms persist in the Tualatin Valley today and can be seen just north of the City of North Plains and in extensive fields along U.S. Route 26 in the western portion of the valley. As is the nature of contemporary agriculture, monoculture crops across the valley both displaced and replaced native vegetation. A process that had begun with the first pioneer farms, native plant and animal displacement caused by agriculture has continued to change vegetation structure and ecosystems throughout the Tualatin Valley.

Following World War II, an economic boom spurred the growth of cities in Washington County (Cieslewicz 2002). At the same time that a baby boom began to occur as men came home from the war to their wives, billions of dollars in war bonds matured and the G.I. Bill financed education, causing the middle class to grow at unprecedented rates. With larger families and incomes, Americans wanted more space to live. Not only did people begin moving out of large cities, such as Portland, in search of more living space in the smaller surrounding communities, but low income farmers and laborers also started to move into towns following higher paying jobs (French 1997). 
Fueled by economic prosperity and a new ideal, people left cities to follow the American dream; so began the era of suburbs. For Washington County, this marked the beginning of a shift from small urban development to large suburban sprawl.

Portlander's continued demand for living space in Washington County provided the impetus for the completion of the Wolf Creek Highway/U.S. Route 26 in 1949. The highway provided an efficient commute to downtown Portland and created numerous opportunities for development such as shopping centers and residential communities. No longer solely an agricultural zone, Washington County, with lower taxes and more space than neighboring Multnomah County, became an attractive option for high-tech industries. Several high-tech companies moved into the area over the next decades; Electro Scientific Industries (ESI) being one of the first in 1962. Later, Tektronics, Intel, Epson, TriQuint Semiconductor and numerous other high-tech businesses followed the trend and also located in Washington County. Since the 1960s, high-tech industries and the establishment of Nike headquarters in 1990 have helped to sustain the population growth that continues today; roads are constantly widened, residential buildings have covered much of the available land, and land-use planning regulations are continuously reevaluated (Buan 1999).

Vastly different from the view that greeted explorers in the early 1800s, the landscape of the Tualatin Valley in 1970 was an urban and agricultural one.

Technological advances and a war that reshaped not only the valley, but much of the rest of the world as well, set the stage for population growth far beyond anything the valley had seen before. Trains, automobiles, suburban housing developments, shopping centers, and high tech industry fill in part of the eastern end of the valley, while farm fields 
blanket the outlying areas (Figure 5). Driving by Tektronics today on a busy suburban street, a person can still see oak trees growing between the road and parking lot, remnants of the former oak savannah ecosystem.

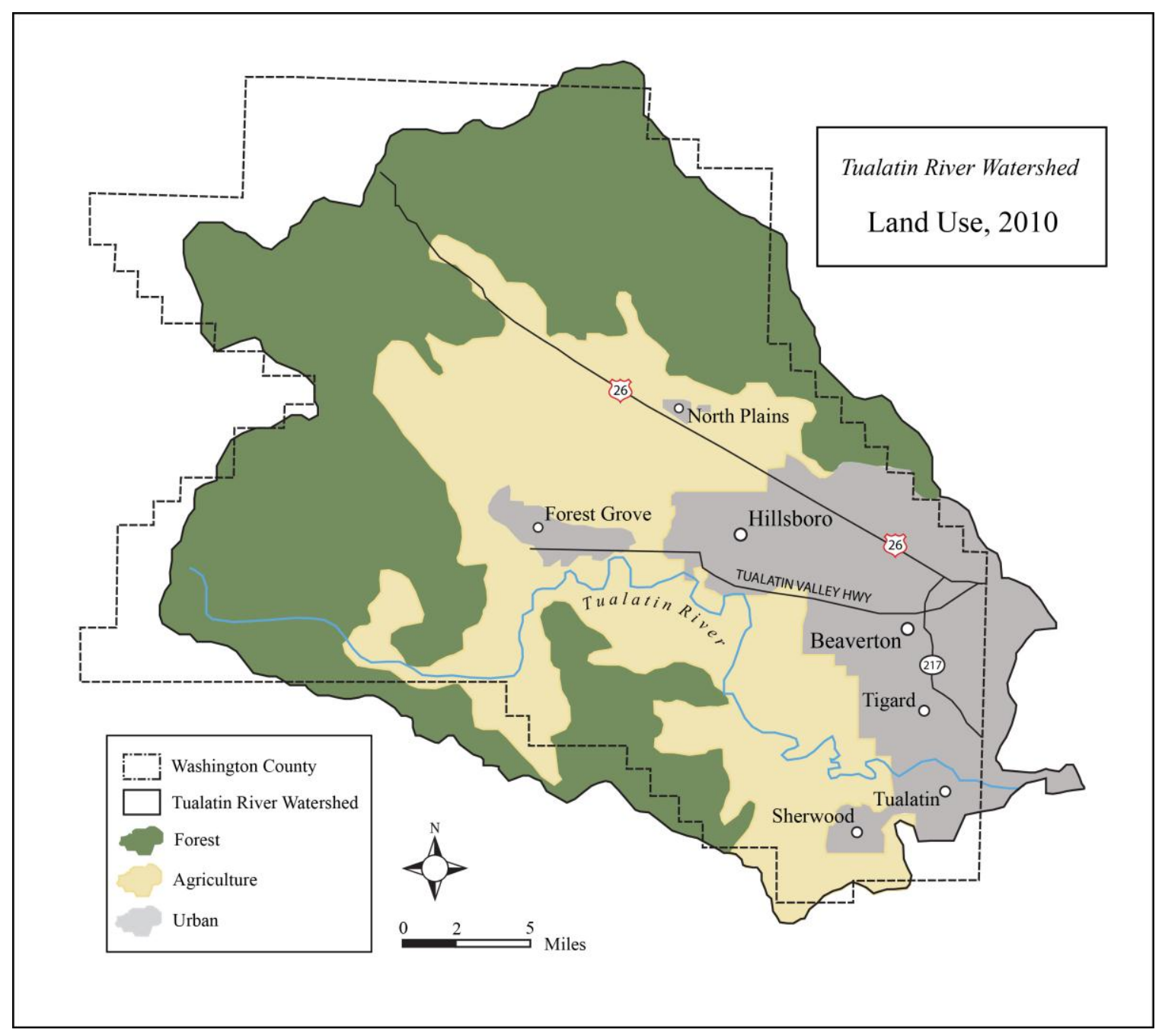

Figure 5. Tualatin River Watershed land use, 2010. 


\section{Modern influence}

The environmental movement that began in the early 1970s and stemmed from changing perspectives about the value of the natural environment resulted in changes throughout the Tualatin Valley. A growing sense of environmental responsibility coupled with scientific evidence of human damage to ecosystems spurred the development of laws and regulations that protect and restore natural systems. Several federal laws that enforce broad-scale environmental protection and safeguard vulnerable species and their habitats from human-caused damage were established during this time and local laws began to take a more specific approach to environmental protection.

One such local approach was the establishment of the Urban Growth Boundary (UGB) in 1973. Through a system of urban and rural reserves, the boundary defines where development can and cannot occur, protecting farms, rural lands, and wildlife habitat from urban sprawl all across Oregon (Figure 5). In Washington County, the boundary controls suburban expansion onto farms and forest lands and has been instrumental in shaping the county's growth patterns (Metro 2012). Restricted development has helped to protect wildlife habitat as well as the farms that are still fundamental to both the local economy and the character of the area.

The population growth and subsequent urbanization that necessitated the establishment of the UGB resulted in a variety of environmental issues. Draining of wetlands resulted not only in major loss of habitat for many plant and animal species, but also the loss of natural water pollution mitigation and flood control. Beginning when fur trappers decimated beaver populations causing vast changes in stream ecology throughout the region, to wetland drainage and rapid urbanization, an accumulation of 


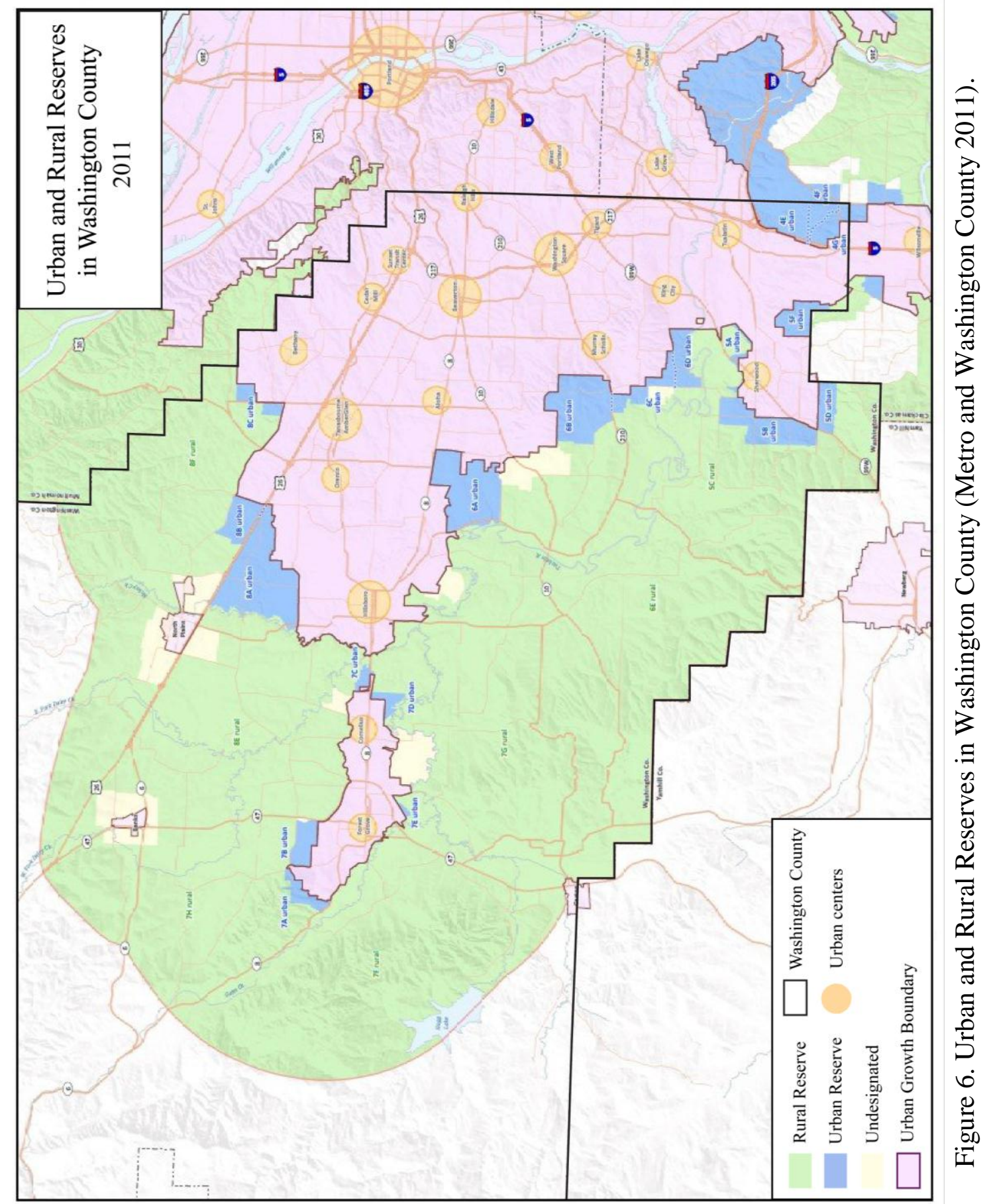


landscape-wide changes in the valley resulted in this once wetland-dominated region to be deemed "water quality limited" in 1987 (Shively 1993). Since the late 1980s, awareness about the ecological services that wetlands provide has increased and national laws have been established to protect and restore wetlands across the country. Section 404(c) of the Clean Water Act gives the Environmental Protection Agency the authority to reject discharge permit requests if the materials discharged would negatively affect municipal water supplies, wildlife, or recreation. Specifically targeted toward wetlands, a program known as "Swampbuster" declares farmers who drain wetlands for the purpose of agriculture ineligible for most federal farm subsidies. Wetland mitigation, also a federal mandate, requires that, if a wetland-drainage permit is granted, a new wetland must be created elsewhere or an existing one restored (Vileisis 1999; Votteler and Muir 2002). The Endangered Species Act was also instrumental in preserving America's, and the Tualatin Valley's, remaining wetlands by requiring that habitat used by species federally recognized as endangered be protected (Vileisis 1999).

Because of these types of federal regulations, along with public demand, wetland preserves have sprung up around the county, providing habitat for a variety of plants, animals, and migratory birds as well as providing pollution mitigation and flood relief to the surrounding region. In 2007, the U.S. Fish and Wildlife Service began drafting plans to restore Wapato Lake to provide nesting and breeding habitat for several different species of birds, mammals, fish, reptiles, and amphibians including the endangered Upper Willamette River Chinook salmon (Oncorhynchus tshawytscha) and the Upper Willamette River steelhead (Oncorhynchus mykiss). Jackson Bottom Wetlands in Hillsboro is a 725 -acre wetland preserve that has a past much like that of Wapato Lake; 
after many years of abuse, the wetland was recovered and today supports diverse plant and animal life while providing environmental services such as flood control, carbon sequestration, and pollution mitigation.

Public demand for clean water and air along with a growing sense that humans are a part of nature, not apart from it, has helped to reshape the way we think about our role in the natural environment. Evidence of changing perspectives can be seen in the places we choose to set aside for enjoyment. In the past, wetland destruction was rooted in contempt for disease-bearing insects and the knowledge that drained wetlands could provide more land for farming. From this point of view, draining wetlands seemed both critical to human health as well as an economic improvement. Not until decades later as science rediscovered the many ecological benefits of wetlands did public opinion shift (Vileisis 1999). Immensely different from perspectives of the first pioneers in the valley who viewed wetlands as health hazards and land-wasters, many people today want to see wetlands restored, native plants re-populated, and wildlife habitat protected. Environmental education has become a priority for many organizations throughout the valley; spreading awareness about local environmental issues is an important step toward creating a viable balance of human use of natural resources in the watershed.

While steps have been taken to begin to restore damaged ecosystems, projected population growth in Washington County has created an increased demand for natural resources, water demand being the most prominent. At the center of this demand is Henry Hagg Lake, a reservoir located about fifteen miles southwest of the City of Hillsboro that was created in order to satisfy municipal and agricultural water needs in the region. Situated in Scoggins Valley, the dam was built between 1973 and 1976 on 
Scoggins Creek thereby creating Henry Hagg Lake. The lake currently stores 56,000 acre feet of water which provides irrigation water for farmland along with drinking and industrial water for the Cities of Hillsboro, Forest Grove, Beaverton, and surrounding communities. The reservoir also supplies river-flow augmentation water during the summer for fish habitat and water quality improvement. Anticipating a doubling in water demands by 2050, several Washington County agencies have created plans that include raising the level of Scoggins Dam to increase the reservoir's holding capacity, taking water from the Willamette River, tapping into ground water, and/or purchasing water from the City of Portland's Bull Run water supply (City of Hillsboro Water Quality Report 2011).

Changing land use patterns and priorities over the past several decades are proof of our power to learn from mistakes and adapt to changing circumstances. These skills have been, and will continue to be, essential in our ability to protect that the natural systems that we, and all other living things, depend on. 


\section{Conclusion}

Human manipulation of land in the Pacific Northwest began thousands of years ago when indigenous populations used fire to create a landscape suited to their needs. The open prairie landscape created by annual burning in the Tualatin Valley created ideal hunting grounds and promoted the growth of particular plant species. The results of this land preparation also appealed to European-American settlers who transformed the land first with agriculture and then with urbanization. Subsequent cultural and environmental changes, including continued population growth and urban development, have created the landscape that we see in the Tualatin Valley today.

In simple terms, the future of the Tualatin Valley has two potential paths. Unmitigated urban expansion could lead to the loss of local farmlands, water shortages, pollution, and further habitat simplification. Workday commutes could become an even greater nightmare of congested highways filled with cars spewing out pollution as thousands of people try to make it home at the same time. Clean air could become a distant memory and, because of water shortages, a vegetable garden a luxury only available to those who can afford it.

The other path, however, is one that depends on our learning from the past and valuing the land that produces our food, the streams that supply our water, and the wetlands that provide habitat for our wildlife. A positive future for the Tualatin Valley depends upon the persistence of environmental education programs, ecologically-minded building practices, and the continued value of sustainable, locally produced food. If current trends persist, this latter prediction is the more likely of the two. Work to restore wetlands has been underway for decades, environmental education programs are 
common, outdoor recreation is popular, farmer's markets take over parking lots every summer, and nearly every supermarket supports locally grown produce. The history of wetlands, their destruction and subsequent restoration, is a hopeful example of what may come in the future as we begin to see ourselves not as separate from the natural environment, but as an element of it (Leopold 1949).

Understanding the past of the Tualatin Valley and the things that make it worth protecting is an integral element to making the future worth protecting as well. The era of short-sightedness may not be over in the Tualatin Valley, but the stirrings of an environmentally-minded transformation are well underway. 


\section{Bibliography}

Barker, Neil. 2000. Portland's Works Progress Administration. Oregon Historical Quarterly 101: 414-41.

Beckham, Dow and Christina Romano. 1977. The Indians of western Oregon: This land was theirs. Coos Bay, OR: Arago Books.

Beckham, Stephen D., Rick Minor and Kathryn A. Toepell. 1981. Prehistory and history of BLM lands in west central Oregon: A cultural resource overview. Eugene, OR: University of Oregon. Anthropological Paper No. 25.

Beckham, Dow. 1990. Swift flows the river: Log driving in Oregon. Coos Bay, OR: Arago Books.

Benson, Robert L. 1975. The glittering plain. In Land of Tuality. Virginia E. Moore (ed.). Hillsboro, OR: Washington County Historical Society.

Bilderback, Ken. 2011. Creek with no name: How the West was won (and lost) in Gaston, Oregon.

Buan, Carolyn M. 1999. This far-off sunset land: A pictorial history of Washington County, Oregon. Virginia Beach, VA: Donning Co.

Bowan, William A. 1978. The Willamette Valley: Migration and settlement on the Oregon frontier. Seattle: University of Washington Press.

Boyd, Robert. 1999. Strategies of Indian Burning in the Willamette Valley. In Indians, fire, and the land in the Pacific Northwest. Robert Boyd ed. Corvallis: Oregon State University Press. 94-138.

Cass, Penny L., and J. Ronald Miner. 1993. The Historical Tualatin River Basin.

Corvallis, OR: Oregon Water Resources Research Institute, Oregon State University.

Center for Columbia River History (CCRH). 2012. The Donation Land Claim Act, 1850. Web. Accessed 27 July 2012. http://www.ccrh.org/comm/.

Christy, John A. and Edward R. Alverson. 2011. Historical vegetation of the Willamette Valley, Oregon, circa 1850. Northwest Science 85(2): 93-107.

Cieslewicz, David J. 2002. The environmental impacts of sprawl. In Urban sprawl: Causes, consequences, and policy responses. Gregory D. Squires, ed. Washington DC: The Urban Institute Press.

City of Hillsboro. 2011. Water Quality Report. Pamphlet. 
Dahl, T.E. 1990. Wetlands: losses in the United States 1780s to 1980s. Washington DC: U.S. Fish and Wildlife Service.

Decker, Doug. 2012. Tillamook Burn. Oregon Encyclopedia Project. Portland State University. Web. Accessed 28 April 2012.

http://www.oregonencyclopedia.org/entry/view/tillamook_burn/

Franklin, Jerry and C.T. Dyrness. 1973 (reprinted 1988). Natural vegetation of Oregon and Washington. Corvallis; Oregon State University Press.

French, Michael. 1997. U.S. economic history since 1945. New York: Manchester University Press.

Habeck, James R. 1961. The original vegetation of the mid-Willamette Valley, Oregon. Northwest Science 35: 65-77.

Hadley, Keith S. 1999. Forest history and meadow invasion at the Rigdon Meadows archaeological site, Western Cascades, Oregon. Physical Geography 20: 116-133.

Jackson, Donald, ed. 1978. Thomas Jefferson to George Rogers Clark, December 4, 1783; George Rogers Clark to Jefferson, February 8, 1784. In Letters of the Lewis and Clark expedition. 2 vols, $2^{\text {nd }}$ edition. Urbana: University of Illinois Press. 654-655.

Johannessen, Carl, William Davenport, Artimus Millet, and Steven McWilliams. 1971. The vegetation of the Willamette Valley. Annals of the Association of American Geographers 61(2): 286-302.

Lang, William, Carl Abbott, Roberta Conner, and Christopher Zinn. 2004. Two centuries of Lewis and Clark: Reflections on the Voyage of Discovery. Portland: Oregon Historical Society Press.

Lepofsky, Dana and Ken Lertzman. 2008. Documenting ancient plant management in the northwest of North America. Botany 86: 129-145.

Matthews, Richard P. 1988. Limited horizons on the Oregon frontier: East Tualatin Plains and the town of Hillsboro, Washington County, 1840-1890. Master's thesis. David Johnson, advisor. Department of History, Portland State University.

Metro. 2012. Urban Growth Boundary. Web. Accessed 15 August 2012. http://www.oregonmetro.gov/index.cfm/go/by.web/id=277

Metro and Washington County. 2011. Urban and Rural Reserves in Washington County. Map. Accessed 15 August 2012. http://media.oregonlive.com/washingtoncounty_impact/photo/urban-rural-reservesmapjpg-a79e6587907aeb67.jpg 
Meyer, Lloyd Carl. 1978. History of logging in Washington County: From the frontier to the future. In Land of Tuality, vol. 3. Hillsboro, OR: Washington County Historical Society.

Miller, Rebecca R. 2010. Is the past present? Historical splash-dam mapping and stream disturbance detection in the Oregon coastal province. Thesis (M.S.) Oregon State University.

Minor, Rick Stephen Dow Beckham, Phyllis E. Lancefield-Steeves, and Kathryn Anne Toepel. 1980. Cultural resource overview of the BLM Salem District: Archaeology, ethnography, history. Eugene: University of Oregon Anthropological Papers No. 20.

Mitsch, W.J. and J.G. Gosselink. 2000. Wetlands. $3^{\text {rd }}$ ed. New York: Wiley and Sons.

Moore, Virginia. 1975. Land of Tuality. Washington County Museum.

Oregon Department of Agriculture (ODA). Case study: Washington County agriculture metrics. Web. Accessed 7 July 2012.

http://oregon.gov/ODA/do_reports_land.shtml\#Case_study_Washington_County_agricu lture_metrics

Oman, Kerry R. 2009. Rejoicing in the beauties of nature: The image of the western landscape during the fur trade. Great Plains Quarterly 29 (4): 301-316.

Oregon Historical Society Museum. Oregon, my Oregon! Exhibit. Portland, OR.

Viewed 8 March 2011.

Robbins, Edward O. 1976. Railroad transportation. In Land of Tuality, vol. 2. Hillsboro, OR: Washington County Historical Society.

Robbins, William G. 1999. Ecological change in the intermontane Northwest. In Indians, fire, and the land in the Pacific Northwest. Robert Boyd, ed. Corvallis: Oregon State University Press. 219-235.

Robbins, William G. 2002. Oregon in depression and war, 1925-1945: The most visible of relief agencies. The Oregon History Project. Web. Accessed 27 July 2012.

http://www.ohs.org/education/oregonhistory/narratives/subtopic.cfm?subtopic_ID=106.

Saikku, Mikko. 2005. This delta, this land: An environmental history of the YazooMississippi floodplain. Athens: University of Georgia Press.

Sedell, James, R. and Karen J. Luchessa. 1982. Using the historical records as an aid to salmonid habitat enhancement. In: Proceedings of the Society of American Foresters, Annual Meeting. Society of American Foresters, Bethesda, MD.

Sedell, James R. and Judith L. Froggatt. 1984. Importance of streamside forests to large 
rivers: The isolation of the Willamette River, Oregon, USA from its floodplain by snagging and streamside forest removal. Internationale Vereinigung für Theoretische und Augewandte Limnologie 22: 1828- 1834.

Shively, David. 1993. Landscape change in the Tualatin Basin following EuropeanAmerican settlement. Corvallis, OR: Oregon Water Resources Research Institute, Oregon State University.

Slater, Francis. 1965. Orenco: once called 'garden spot'. Hillsboro Argus, May 13, 1965.

Taft, Oriane W. and Susan M. Haig. 2003. Historical wetlands in Oregon's Willamette Valley: Implications for restoration of winter waterbird habitat. Wetlands 23(1): 51-64.

Tobie, Harvey E. 1949. No man like Joe: The life and times of Joseph L. Meek. Portland: Binford and Mort for the Oregon Historical Society.

Towle, Jerry C. 1982. Changing geography of Willamette Valley woodlands. Oregon Historical Quarterly 83(1): 66-87.

Tualatin River Watershed Council (TRWC). 2012. Web. Accessed 13 June 2012. http://www.trwc.org/.

Tucker, Kathy. 2002. Workmen battle mud, Wolf Creek Highway. The Oregon History Project. Web. Accessed 27 July 2012.

http://www.ohs.org/education/oregonhistory/historical_records/dspDocument.cfm?doc_I $\mathrm{D}=000 \mathrm{DC} 39 \mathrm{~A}-\mathrm{B} 0 \mathrm{C6}-1 \mathrm{E} 35-925 \mathrm{~B} 80 \mathrm{~B} 05272006 \mathrm{C}$

U.S. Census Bureau. 2012a. Population of counties by decennial census: 1900 to 1990. Compiled and edited by Richard L. Forstall. Web. Acessed 16 August 2012. http://www.census.gov/population/cencounts/or190090.txt

U.S. Census Bureau. 2012b. State and county quick facts: Washington County, Oregon. Web. Accessed 16 August 2012. http://quickfacts.census.gov/qfd/states/41/41067.html

U.S. Fish and Wildlife Service (USFWS). 2007. Tualatin River National Wildlife Refuge Wapato Lake unit addition land conservation plan and environmental assessment. Web. Accessed 7 July 2012.

http://www.fws.gov/pacific/planning/main/docs/OR/Wapato/Final\%20LCP\%20EA/2\%20 Wapato\%20FONSI\%20EA\%20LCP.pdf.

Votteler, Todd H. and Thomas A. Muir. 2002. Wetland management and research, wetland protection legislation. U.S. Geological Survey. Accessed online 9 July 2012. http://water.usgs.gov/nwsum/WSP2425/legislation.html

Vale, Thomas R. 2005. The American wilderness: Reflections on nature protection in the United States. Charlottesville: University of Virginia Press. 
Vancouver, George. 1791-1795. A voyage of discovery to the North Pacific Ocean and round the world, vol. II. W. Kaye Lamb, ed. London 1984, 568.

Victor, Frances Fuller. 1985. The river of the West: The adventures of Joe Meek. Missoula: Mountain Press Publishing Company.

Vileisis, Ann. 1999. Discovering the unknown landscape: A history of America's wetlands. Washington, D.C.: Island Press.

Walsh, M.K., C.A. Pearl, C. Whitlock, and P.J. Bartlein. 2010. An 11,000-year-long record of fire and vegetation history at Beaver Lake, Oregon, central Willamette Valley. Quaternary Science Reviews 29: 1093-1106.

Wells, Gail. 1999. The Tillamook: A created forest comes of age. Corvallis: Oregon State University Press.

Western Regional Climate Center (WRCC). 2003. Web. Accessed 13 June 2012. http://www.wrcc.dri.edu/.

Woodger, Elin and Brandon Toropov. 2004. Encyclopedia of the Lewis and Clark expedition. NewYork: Facts on File.

Zenk, Henry. 1976. Contributions to Tualatin ethnography: Subsistence and ethnobiology. Master's thesis. Portland State University.

Zyback, Bob. 1990. Historic Soap Creek Valley. Corvallis, OR: OSU Book Stores, Inc. 5. 